\title{
Crude protein changes on grassland along a degradation gradient in a semi-arid climate
}

\author{
H.A. Snyman \\ Department of Animal, Wildlife and Grassland Science, University of the Free State, P.O. Box 339, \\ Bloemfontein 9300, South Africa
}

\begin{abstract}
The aim with this investigation was to quantify the impact of different veld condition classes, viz. poor, moderate and good on soil-water utilization (SWU: crude protein produced per unit of evapotranspiration), during four growing seasons (2000/01 - 2003/2004). Evapotranspiration was determined by quantifying the soil-water balance equation with the aid of runoff plots and soil-water content measurements. Crude protein (CP) content was calculated from measured nitrogen content (Kjeldahl method) of the leaves, stems and seed. Although the monthly CP concentration $(\mathrm{g} / \mathrm{kg})$ of grassland in poor condition was generally higher than that of grassland in good condition, CP production decreased significantly with veld degradation when expressed as total quantity $(\mathrm{kg} / \mathrm{ha})$ of dry matter produced. Grassland in good, moderate and poor condition produced on average over the season 141, 97 and $32 \mathrm{~kg}$ $\mathrm{CP} /$ ha, respectively. Both monthly and seasonal SWU declined significantly with grassland degradation. Grassland in good condition averaged a SWU of $0.32 \mathrm{~kg} \mathrm{CP} / \mathrm{ha} / \mathrm{mm}$ during the four growing seasons, compared to the only $0.09 \mathrm{~kg} \mathrm{CP} / \mathrm{ha} / \mathrm{mm}$ produced from veld in poor condition. The study shows that it is important to keep grassland in optimal condition to utilize limited soil water for sustainable plant and therefore animal production.
\end{abstract}

Keywords: Crude protein, evapotranspiration, soil-water content, soil-water utilization, veld condition

\# E-mail: Snymanha.sci@ufs.ac.za

\section{Introduction}

Approximately $65 \%$ of South Africa's grasslands is classified as arid to semi-arid. Since rainfall is the limiting environmental factor determining grassland production in these arid and semi-arid areas (Snyman, 1998), sustainable utilization of the grassland ecosystem must emphasize the capturing and efficient use of water. In these drier areas, grassland is frequently subjected to seasonal droughts that may lead to instability in farming systems and necessitates a high standard of risk management (Oosthuizen et al., 2006). Although the livestock farmer cannot control the rainfall on his farm, he can directly and/or indirectly influence its effectiveness, since grassland condition is influenced by management practices. Selecting the correct stocking rate is the most important of all grazing management decisions and is based on sustainable use of vegetation, livestock and wildlife production, and economic return (Van der Westhuizen et al., 2005). It is therefore important to apply stocking rates based on estimated grazing capacity, which will allow for the sustainable utilization of the grassland ecosystem as stocking rate is the most important factor influencing: rangeland condition, available grazing material, sensitivity to drought periods, animal performance and gross income (Snyman, 1998). In calculating water-use efficiency or water utilization, most researchers (Le Houérou, 1984) only express it in terms of the quantity of dry matter (DM) produced per unit water consumed, while its calculation in terms of crude protein $(\mathrm{CP})$ produced per unit of water consumed, receives little attention at present. The latter calculation can make a large contribution to the estimation of short-term nutritive value of grassland, given the quantity of rainfall received or water consumed. The ability of grassland to efficiently utilize limited soil water in a semi-arid climate was therefore investigated along a degradation gradient.

\section{Material and Methods}

The research was conducted at Bloemfontein (28 $50^{\prime} \mathrm{S} ; 2^{\circ} 15^{\prime} \mathrm{E}$, altitude $1350 \mathrm{~m}$ ), which is situated in the semi-arid summer rainfall (annual average $560 \mathrm{~mm}$ ) region of South Africa. The data were collected 
from a typical Dry Sandy Highveld grassland. The soil was a fine, sandy, loam soil of the Bloemdal Form (Soil Classification Working Group, 1991). The percentage of clay increased down the profile from 10\% in the A-horizon $(0-300 \mathrm{~mm}$ depth) to $24 \%$ in the B1-horizon $(300-600 \mathrm{~mm})$ and $42 \%$ in the B2-horizon (600-1200 mm depth).

The experimental layout was a fully randomized design consisting of three treatments with three replications. Rangelands in three different compositional classes (good, moderate and poor) were studied over the 2000/01 to 2003/04 seasons. The research was conducted on nine plots of $10 \times 10 \mathrm{~m}^{2}$ each, which were randomly set out on the same soil form. All plots were excluded from livestock grazing during the four year trial period. Grassland condition was determined according to the method of Foran et al. (1978). Soilwater utilization (SWU) was defined as the quality (CP) of DM produced per unit of water evapotranspired. Herbage production, that was determined for each grassland condition class by clipping plants to a height of $30 \mathrm{~mm}$ in eight randomly selected quadrats of $1 \mathrm{~m}^{2}$ for each treatment, was used to determine nitrogen $(\mathrm{N})$ content (Technicon, 1977) following Kjeldahl digestion of the plant material in concentrated sulphuric acid. Crude protein calculated from $\mathrm{N}$ content of the whole aboveground organs (leaves, stems and seeds) was determined in the middle and end of each month. Evapotranspiration was determined by quantifying the soil-water balance equation (Snyman, 1998). The soil-water content was monitored every fourth day with the aid of a neutron hydroprobe at $200 \mathrm{~mm}$ depth intervals. All data were analyzed, using a one-way ANOVA (Winer, 1974), with the procedures of SAS (DOS program, 6.04 version) applied (Cary, 1988). Least significant differences (LSD) were calculated at the 1\% level (Fisher, 1949).

\section{Results and Discussion}

The average rangeland condition scores (expressed as a percentage of that in a benchmark site) were $88.14,61.71$ and $31.06 \%$, respectively for veld in good, moderate and poor condition, with a basal cover of $8.85,6.01$ and $3.20 \%$, respectively.

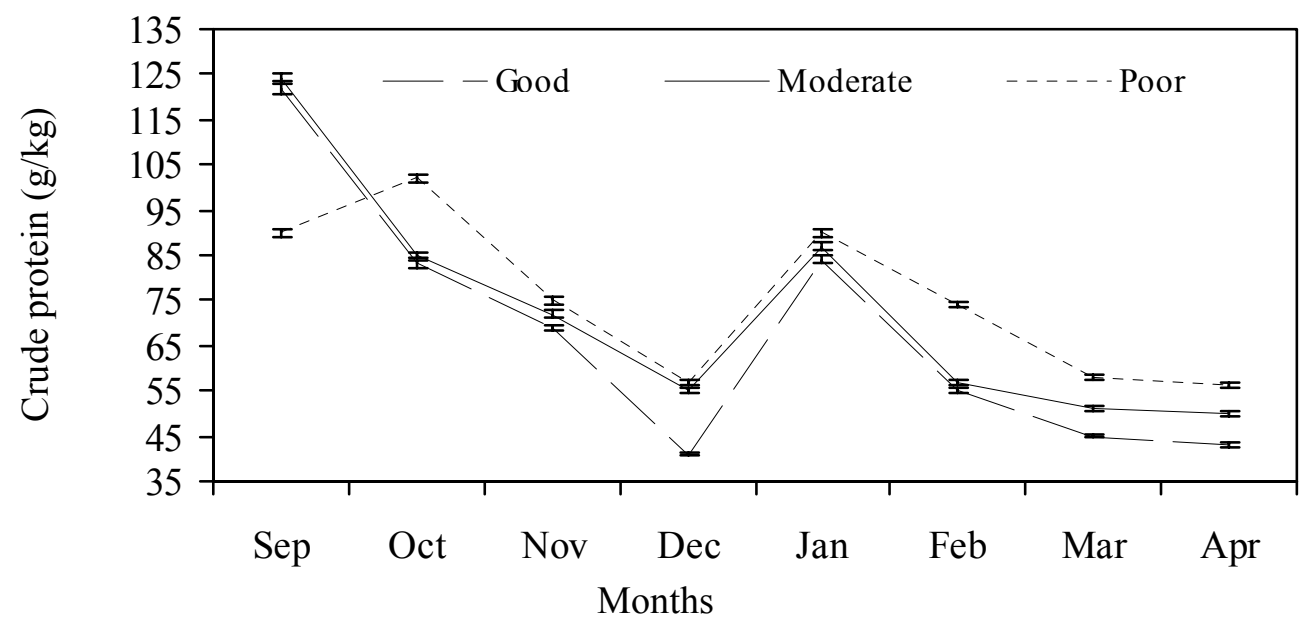

Figure 1 Average crude protein concentrations for different veld conditions as measured during the middle and end of each month for the 2000/01 to 2003/04 growing seasons. LSD $_{0.01}=0.42$. Vertical bars are standard errors of means

The highest CP levels occurred in middle September, where it formed an average ( \pm s.e.) of 126.6 $\pm 31.2 \mathrm{~g} / \mathrm{kg}$ and $128.1 \pm 33.6 \mathrm{~g} / \mathrm{kg}$ of the DM for grasslands in good and moderate condition, respectively (Figure 1). The grasslands in poor condition had the highest $(\mathrm{P} \leq 0.01)$ monthly $\mathrm{CP}$ concentrations during the growing season except for the beginning of the growing season (September and the beginning of 
October). The lower $\mathrm{CP}$ content found in plant material as grassland condition improved, was possibly caused by its mobilization (growth reserves) for high DM production per unit area delivered.

The gradual decrease in CP concentration occurring after the spring and reaching a low at the end of December can be ascribed to most of the plants being in full seed at that stage and gradually becoming dormant (Figure 1). The CP ( \pm s.e.) content of the grassland in good condition was as low as $40.1 \pm 6.1 \mathrm{~g} / \mathrm{kg}$ $\mathrm{DM}$ at the end of December, almost similar to that reached in mid-April when the first frost occurred. Most of the growing season was characterized by a mid-summer drought (middle December to middle January) that could also have contributed to a decrease in CP. The study area is normally characterized by a second growth cycle, which usually starts during the middle of January, resulting in a second peak in CP concentrations at the end of January. During most seasons, at about the middle of February, the grasses started becoming reproductive again, with a rapid decrease in CP content as the season progressed and the plants became dormant. Remarkably, similar seasonal variation and trends in CP content of the diet selected by oesophageally fistulated sheep on the same veld type are well documented (De Waal, 1990).

Grassland in good condition produced on average ( \pm s.e.) $1899 \pm 214 \mathrm{~kg} \mathrm{DM} / \mathrm{ha} / \mathrm{season}$, those in moderate condition $1007 \pm 196 \mathrm{~kg} \mathrm{DM} / \mathrm{ha} /$ season and veld in poor condition $369 \pm 102 \mathrm{~kg} \mathrm{DM} / \mathrm{ha} / \mathrm{season}$, which differed $(\mathrm{P} \leq 0.01)$ from each other. These results validate/confirm the rangeland condition scoring system used to classify the veld as good, moderate and poor. The seasonal CP production (expressed in $\mathrm{kg} / \mathrm{ha}$ ) of $141 \pm 31,97 \pm 21$ and $32 \pm 11 \mathrm{~kg} \mathrm{CP} / \mathrm{ha}$ for grassland in good, moderate and poor condition respectively, also differed $(\mathrm{P} \leq 0.01)$ between the different grassland condition classes, as expected. Even though the grassland in a poor condition had for most of the year a higher $(\mathrm{P} \leq 0.01)$ monthly seasonal $\mathrm{CP}$ level $(\mathrm{g} / \mathrm{kg})$ than the grassland in good condition, the $\mathrm{CP}$ expressed in $\mathrm{kg}$ per ha was much lower $(\mathrm{P} \leq 0.01)$ due to the lower $(\mathrm{P} \leq 0.01)$ aboveground $\mathrm{DM}$ production accompanying veld degradation.

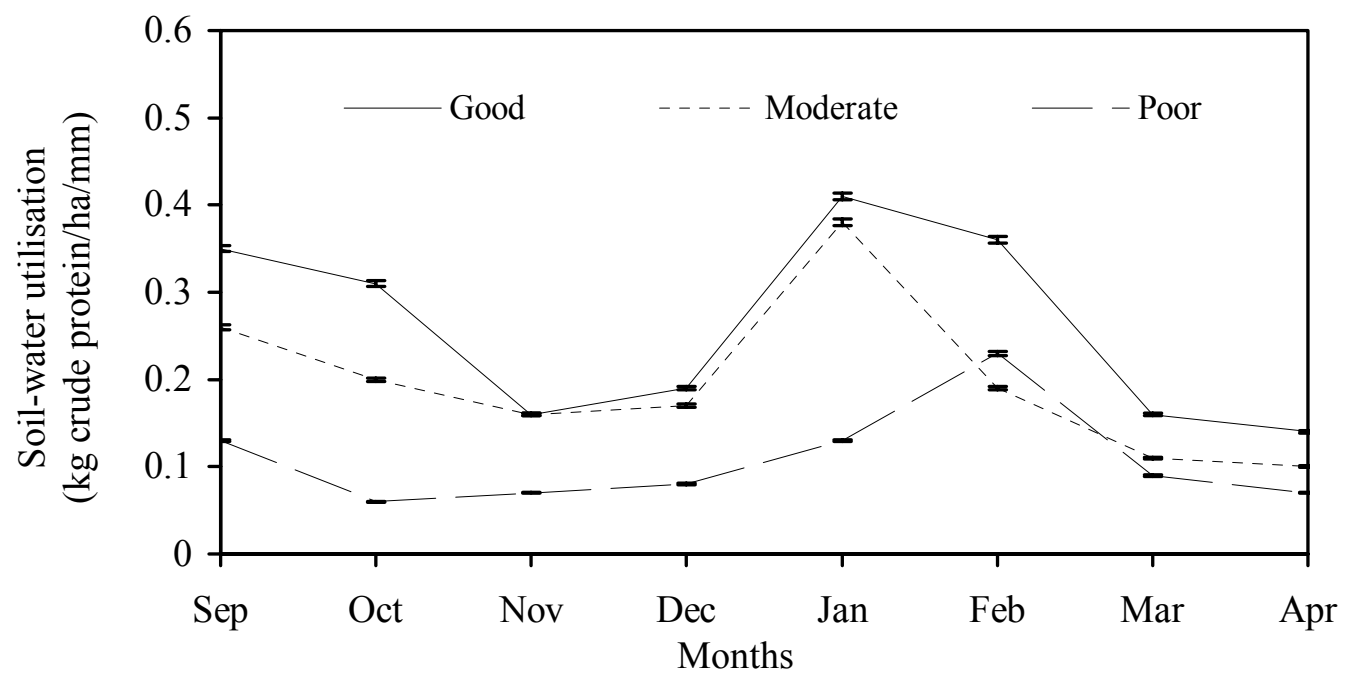

Figure 2 Monthly average soil-water utilization $(\mathrm{kg} \mathrm{CP} / \mathrm{ha} / \mathrm{mm})$ for the different veld conditions for the 2000/01 and 2003/04 growing seasons. LSD $_{0.01}=0.06$. Vertical bars are standard errors of means

On average ( \pm s.e.) over the four growing seasons, veld in good, moderate and poor condition produced $0.32 \pm 0.09,0.25 \pm 0.06$ and $0.09 \pm 0.02 \mathrm{~kg} \mathrm{CP} / \mathrm{ha}$, respectively for each $\mathrm{mm}$ water used. Regardless of the quantity of rainfall occurring over the growing season, a grassland in poor condition had a notably lower $(\mathrm{P} \leq 0.01)$ production in $\mathrm{CP}$ per area. The better the grassland condition, the more effective the reaction obtained in terms of CP production per hectare (Figure 2). The monthly and seasonal SWU decreased $(\mathrm{P} \leq 0.01)$ with veld degradation. Only during the months November to January SWU for veld in 
good and moderate conditions did not differ significantly $(\mathrm{P}>0.05)$. Only for February the SWU for veld in poor condition was higher $(\mathrm{P} \leq 0.01)$ than that of veld in a moderate condition. The highest seasonal SWU ( \pm s.e.) occurred during the $2000 / 01$ seasons, during which rangeland in good, moderate and poor conditions produced $0.38 \pm 0.03 ; 0.27 \pm 0.02 ; 0.10 \pm 0.01 \mathrm{~kg} \mathrm{CP} / \mathrm{ha} / \mathrm{mm}$, respectively. Veld in good and moderate condition used water most efficiently during January, while the most efficient water use for veld in poor condition occurred in February. On the same semi-arid grassland Snyman (1999; 2005) also recorded the highest water use during the last half of the growing season.

The low SWU during November/December and March/April occurred within the reproductive phase of most grass species within a specific veld condition. Most grasses underwent another active growth cycle after the reproductive phase at the end of December, which can be observed in Figure 2 in the SWU increase, due to an increase in CP. These increases are in agreement with findings of most researchers (Snyman, 1999; 2000; Van der Westhuizen et al., 2005) that grasslands in these drier areas produce their total DM yield per season over only four to five months of the year. Therefore, the fodder must be distributed to the non-productive months for constant fodder flow planning and sustainable grassland management.

\section{Conclusions}

It is clear that grassland in good condition does not only deliver a higher DM production than degraded veld, but also has a significantly higher total CP content and better soil-water utilization than grassland in poor condition. Soil-water utilization (expressed in $\mathrm{kg} \mathrm{CP}$ for each $\mathrm{mm}$ of evapotranspiration) is a convenient and suitable tool to evaluate the productivity of a grassland ecosystem. Fodder flow planning and veld risk management for livestock production are more complicated in grassland in poor condition due to lower production and soil-water utilization efficiency. The efficiency and risk with which rainfall is converted into plant production by fodder plants and eventually gross farming income from the basis of sustainability of extensive ruminant production on a grassland ecosystem.

\section{References}

Cary, R.C., 1988. SAS Institute Inc. SAS Dos program 6.04, USA. 1028 pp.

De Waal, H.O., 1990. Animal production from native pasture (veld) in the Free State Region - A perspective of the grazing ruminant. S. Afr. J. Anim. Sci. 20, 1-9.

Fisher, R.A., 1949. The design of experiments. Oliver and Boyd Ltd., Edinburg. pp. 214.

Foran, B.D., Tainton, N.M. \& Booysen, P.deV., 1978. The development of a method for assessing veld condition in three grassveld types of Natal. Proc. Grassld. Soc. Sth. Afr. 13, 27-34.

Le Houérou, H.N., 1984. Rain-use efficiency: A unifying concept in arid-land ecology. J. Arid Environ.7, 213-247.

Oosthuizen, I.B., Snyman, H.A. \& Pretorius, J.C., 2006. Protein concentration in response to water stress in Themeda triandra Forsk. S. Afr. J. Plant Soil. 23, 43-48.

Snyman, H.A., 1998. Dynamics and sustainable utilization of the rangeland ecosystem in arid and semi-arid climates of southern Africa. J. Arid Environ. 39, 645-666.

Snyman, H.A., 1999. Quantification of the soil-water balance under different veld conditions in a semi-arid climate. Afr. J. Range For. Sci. 16, 108-117.

Snyman, H.A., 2000. Soil-water utilization and sustainability in a semi-arid grassland. Water S.A. 26, 333341.

Snyman, H.A., 2005. Rangeland degradation in a semi-arid South Africa- 1: Influence on seasonal root distribution, root/shoot ratios and water-use efficiency. J. Arid Environ. 60, 457-481.

Soil Classification Working Group, 1991. Soil Classification: A Taxonomic System for South Africa. Department of Agriculture Development, Pretoria. 226 pp.

Technicon., 1977. Individual/simultaneous determination of nitrogen and/or phosphorus in BD acid digests. Industrial Method No. 334-374 W/B Technicon Industrial Systems, Tarrytown, New York. 215 pp.

Van der Westhuizen, H.C., Snyman, H.A. \& Fouchè, H.J., 2005. A degradation gradient for the assessment of rangeland condition of a semi-arid sourveld in southern Africa. Afr. J. Range For. Sci. 22, 47-58.

Winer, B.J., 1974. Statistical Principles in Experimental Design. McGraw-Hill, London. pp. 218. 